\title{
Antimicrobial Activity of Aloe sinkatana
}

\author{
ABUBAKER ALI ${ }^{1}$, ELHAM ABDELBASIT SULEIMAN ${ }^{2}$, \\ AMIR SAEED ${ }^{3}$, AND GUNNAR SANDSTRÖM ${ }^{3 *}$

\begin{abstract}
${ }^{\prime}$ University of Medical Sciences and Technology, Faculty of Medical Laboratory Sciences, Khartoum 12810, Sudan;
${ }^{2}$ Veterinary Research Institute Department of Mycology, Khartoum 12810, Sudan;

${ }^{3}$ Karolinska Institute, Department of Laboratory Medicine, Division of Clinical Microbiology, Karolinska University Hospital, Huddinge, SE-14186 Stockholm, Sweden
\end{abstract}

\begin{abstract}
Aloe sinkatana is a plant belonging to the family Xanthorrhoeaceae, subfamily Asphodeloideae, genus Aloe. It is cultivated in the Red Sea Mountainseastern of the Sudan. In the present study, the extract of $A$. sinkatana leaves was screened for its antibacterial and antifungal activity. The phytochemical screening of $A$. sinkatana extracts was carried out using Thin Layer Chromatography (TLC) technique. Four extracts of $A$. sinkatana were prepared using chloroform, ethanol, methanol, and water. Antibacterial activity of the extract was performed following the cup-plate agar diffusion method. Also, the antifungal activity of the extract was tested. The result showed that the extracts of $A$. sinkatana leaves revealed antimicrobial activities greater than the commercial antifungal (Nystatin) which can be used for treatment of Candidiasis and ketoconazole that is used for treatment of fungal infection. The antimicrobial activity might be due to specific plant compounds, which was found to be more effective than commercial antifungal compounds. However the commercial antibiotic used for treatment of bacterial infection, displayed better antimicrobial activity than the $A$. sinkatana extracts. In conclusion $A$. sinkatana extract can be a useful treatment against fungal infections.
\end{abstract}

Key words: Aloe sinkatana, antibacterial, antifungal

Aloe sinkatana adalah tanaman yang termasuk keluarga Xanthorrhoeaceae, subfamili Asphodeloideae, genus Aloe . Tanaman ini dibudidayakan di Red Sea Mountainseastern, Sudan . Dalam penelitian ini, dilakukan skrining aktivitas antibakteri dan antijamur dari ekstrak daun A. sinkatana. Skrining secara fitokimia dari ekstrak A. sinkatana dilakukan dengan menggunakan teknik kromatografi lapis tipis ( KLT ). Enam jenis ekstrak $A$. sinkatana dipersiapkan dalam kloroform, etanol, metanol, dan air. Aktivitas anti bakteri dari ekstrak dilakukan mengikuti metode cup-plate agar diffusion. Demikian pula dilakukan uji aktivitas antijamur telah dilakukan. Hasil penelitian menunjukkan bahwa ekstrak dari $A$. sinkatana mengungkapkan kegiatan antimikroba lebih besar daripada anti jamur komersial, nistatin, yang digunakan untuk pengobatan Candidiasis, dan ketoconazolethat yang digunakan untuk pengobatan infeksi jamur. Aktivitas anti mikroba mungkin disebabkan karena senyawa tertentu, yang lebih efektif daripada senyawa anti jamur komersial. Akan tetapi, antibiotik komersial untuk pengobatan infeksi bakteri, mempunyai aktivitas anti mikroba lebih baik daripada ekstrak $A$. sinkatana. Sebagai kesimpulan ekstrak $A$. sinkatana berpotensi sebagai obat infeksi jamur.

Kata kunci: Aloe sinkatana, anti bakteri, anti jamur

Aloe sinkatana is a clumping rosettes plant belonging to family Xanthorrhoeaceae, subfamily Asphodeloideae, genus Aloe. It is found in Eastern of Sudan in Red Sea Mountains mainly in Arkawit area. The plant is up to $60 \mathrm{~cm}$ tall and $60-90 \mathrm{~cm}$ in diameter (Reynolds 1957).

The active component in Aloe vera is Anthraquinone glycosides; which is an aromatic organic compound with the formula $\mathrm{C}_{14} \mathrm{H}_{8} \mathrm{O}_{2}$ with several isomers, each of them is known as a quinone derivative. Three different solvents such as water, ethanol and acetone were used to extract the bioactive compounds from the leaves of $A$. vera to screen the antimicrobial activity of selected human pathogens by agar diffusion method. The

*Corresponding author; Phone/Fax: +46-8-524-832-79, Email: gunnar.sandstrom@ki.se antifungal activity of $A$. vera was analysed against Aspergillus flavus and Aspergillus niger. The maximum antifungal activity was observed in acetone extracts when compared with other extracts. A. vera plant extract with acetone can be used as antimicrobial agents (Arunkumar and Muthuselvam 2009).

The comparative antimicrobial activities of the gel and leaf of $A$. vera were tested against Staphylococcus aureus, Pseudomonas aeruginosa, Trichophytonmenta graphytes, T. schoeleinii, Microsporium canis, and Candida albicans (Pandey and Mishra 2010). Ethanol was used for the extraction of the leaf after obtaining the gel from it. Antimicrobial effect was measured by the appearance of zones of inhibition (Pandey and Mishra 2010; du Plessis and Hamman 2013).

Antimicrobial susceptibility test showed that both the gel and the leaf inhibited the growth of $S$. aureus. 
Only the gel inhibited the growth of T. mentagrophytes while the leaf possesses inhibitory effects on both $P$. aeruginosa and $C$. albicans. The results of this stimulate the use of both $A$. vera gel and leaf (O et al. 2005; Pandey and Mishra 2010). The aim of this study is to test the antimicrobial activities of the A. sinkatana. There is no work done on $A$. sinkatana so far and accordingly, this is the first report on investigation on its antimicrobial activity.

\section{MATERIALS AND METHODS}

Plant Material. A. sinkatana plant was obtained from faculty of Pharmacy collection at the University of Medical Science and Technology, Khartoum, Sudan.

Preparation of the Crude Extracts. Coarsely powdered $A$. sinkatana leaves $(80 \mathrm{~g})$ were extracted for twenty hours with chloroform in soxhlet apparatus. The chloroform extract was filtered and evaporated under reduced pressure. The extracted leaves were airdried, re-packed in soxhlet till exhaustively extracted with methanol. The methanolic extract was filtered and evaporated under reduced pressure. The residue of chloroform was re-dissolved in a mixture of petroleum ether and methanol in the ratio of $(1: 2 \mathrm{v} / \mathrm{v})$ and the methanol extract was re-dissolved in methanol. The final product was kept in a refrigerator till used. Simultaneously, water extract was prepared by adding $10 \mathrm{~mL}$ of boiled distilled water to a sample of $10 \mathrm{~g}$ of the coarsely powdered plant materials in a beaker, with occasional shaking for four hours and the final volume was adjusted to $10 \mathrm{~mL}$ with boiled distilled water at a temperature of $25^{\circ} \mathrm{C}$. The aqueous extract was filtered and the precipitate was washed in distilled water and the filtrate was used immediately (Almagboul, 1992).

Phytochemical Screening of $A$. sinkatana Extracts. The phytochemical screening was carried out according to qualitative methods described. Six extracts have been obtained such as chloroform extract, methanol extract, and aqueous extract. The powdered dried samples of the leaves of A. sinkatana were separately screened for the following constituents: carbohydrates and/or glycosides, tannins, flavonoids, saponins, alkaloids and/or nitrogenous bases, anthraquinons, unsaturated sterols and/or triterpenes, and coumarins using water and organic solvents according to the required material.

Preparation of the Test Organisms. One $\mathrm{mL}$ of a $24 \mathrm{~h}$ broth culture of the test organism was aseptically distributed onto nutrient agar slopes and incubated at 37 ${ }^{\circ} \mathrm{C}$ for $24 \mathrm{~h}$. The bacterial were harvested and washed in sterile normal saline, and suspended in a small volume of normal saline to produce a suspension containing about $10^{8}-10^{9}$ colony forming units per $\mathrm{mL}$. The suspension was stored in a refrigerator at $4{ }^{\circ} \mathrm{C}$ till used. The average number of viable organism per $\mathrm{ml}$ of the stock suspension was determined by means of the surface viable counting technique (Miles and Amyes, 1996). Serial dilutions of the stock suspension were made in sterile normal saline, and dropping pipettes to the surface of dried nutrient agar plates transferred 0.02 $\mathrm{mL}$ of the appropriate dilutions. The plates were allowed to stand for $2 \mathrm{~h}$ at room temperature, following incubation at $37{ }^{\circ} \mathrm{C}$ for $24 \mathrm{~h}$. After incubation the number of colonies in each drop was counted. The average number of colonies per drop $(0.02 \mathrm{~mL})$ was multiplied by 50 and by the dilution factor to give the viable count of stock suspension, expressed as the number of colony forming units per $\mathrm{mL}$ of suspension. Each time a fresh stock suspension was prepared.

Antibacterial Activity of the Extract. The cupplate agar diffusion method (Kavanagh, 1972), was adopted with some minor modification to assess the antibacterial activity of the prepared extracts. One $\mathrm{mL}$ of the standardized bacterial stock suspension $\left(10^{8}-10^{9}\right.$ colony forming units per $\mathrm{mL}$ ) was thoroughly mixed with $100 \mathrm{~mL}$ of sterile molten Muller-Hinton agar, which was maintained at $45^{\circ} \mathrm{C} .20 \mathrm{~mL}$ aliquots of the inoculated Muller and Hinton agar were distributed into sterile Petri dishes. The agar was left to set. On each of these plates, four cups (10 $\mathrm{mm}$ in diameter) were cut using a sterile cork borer and agar discs were removed. The cups were filled with $0.1 \mathrm{~mL}$ sample of each of the extract using standard fine pipette adjustable volume digital pipette, and allowed to diffuse at room temperature for two hours. The plates were incubated in the upright position, at $37^{\circ} \mathrm{C}$ for $18 \mathrm{~h}$. Three replicates were made for each extract against each of the tested organisms. Simultaneously, positive control was inoculated using respective solvents. After incubation, the diameters of the resultant growth inhibition zones were measured. The average mean values were tabulated. To determine whether the plant extracts were bacteriostatic or bactericidal subcultures were made from within the zones of inhibition onto Muller and Hinton agar and incubated at $37{ }^{\circ} \mathrm{C}$ for $24 \mathrm{~h}$. Then the plates were examined for bacterial growth. Growth of the organism indicates the bacteriostatic activity of extract and no growth indicates its bactericidal effect.

Antifungal Activity of The Extracts. The fungal tested organism A. flavus and A. niger were spread over the Sabouraud's dextrose agar plates after the 
microbial, four cups (10 $\mathrm{mm}$ in diameter) were cut using a sterile cork borer and agar discs were removed. The cups were filled with $0.1 \mathrm{~mL}$ samples of each of the extract, and allowed to diffuse at room temperature for $2 \mathrm{~h}$. The plates were incubated in the upright position, at $30{ }^{\circ} \mathrm{C}$ for $72 \mathrm{~h}$. Three replicates were made out for each extract against each of the tested organisms. Simultaneously, positive control was involved by adding respective solvents instead of the extracts. After incubation, the diameters of the resultant growth inhibition zones were measured in $\mathrm{mm}$, the average mean values were tabulated.

For other fungal tested organisms, one $\mathrm{mL}$ of the extract was thoroughly mixed with $100 \mathrm{~mL}$ of sterile molten Sabouraud's dextrose agar which was maintained at $45{ }^{\circ} \mathrm{C}$. Twenty $\mathrm{mL}$ aliquots of the inoculated Sabouraud's dextrose agar were distributed into sterile petri-dishes. The agar plates were left to set; the test organisms were inoculated in the center of plate. Positive control was inoculated in the same manner as above.

Antimicrobial Susceptibility-Test Susceptibility Test Procedure. Plates with Mueller and Hinton agar were prepared according to a method previously described (Bauer and Driesen 1966). For rapidly growing aerobic organisms, 3-4 similar colonies from pure cultures as inoculum were selected and transferred into $5 \mathrm{~mL}$ of Tryptone Soya Broth. Incubation was performed at $35{ }^{\circ} \mathrm{C}$ for $2-8 \mathrm{~h}$ until moderate turbidity developed. A sterile non-toxic cotton swab on a wooden applicator was dipped into the standarized inoculum and the soaked swab was firmly rotated against the upper inside wall of the tube angle between each streaking. The inoculum was allowed to dry for 515 min with lid in place. Using aseptic technique the discs were applied. The discs with centers at least 24 $\mathrm{mm}$ apart were deposited. For Penicillin and Cephalosporin, the discs were deposited with centers $30 \mathrm{~mm}$ apart. The plates were incubated immediately at $37{ }^{\circ} \mathrm{C}$ and examined after $14-19 \mathrm{~h}$. Zones showing complete inhibition was measured (Bauer and Driesen 1966).

\section{RESULT}

The Antimicrobial Activity against $S$. arues, $E$. coli, and $P$. aerginosa. The antimicrobial activity of different antibiotica and A. sinkatana in different solvent systems against $S$. arues, E. coli, and $P$. aerginosa was estimated and revealed inhibition zones (Table 1). In comparison virtually no difference could be seen between antibiotica tested and extracts from $A$. sinkatana tested.

The antimicrobial activity of different antibiotica and $A$. sinkatana in different solvent systems against $C$. albicans, A. niger, A. flavus, T. mentaegraphytes, and Phialophorarichardsiae revealed inhibition zones (Table 2). All dermatophytes tested revealed sensitivity to all extracts. Furthermore, no growth was observed on Sabouraoud dextrose agar after A. sinkatana extracts treatment. Thus, the extracts of $A$. sinkatana tested against dermatophytes included in experiments

Table 1 Effect of Aloe sinkatanain in different solvent systems and antibiotic against against Staphylococcus aureus, Escherichia coli, and Pseudomonas aeruginosa

\begin{tabular}{llccc}
\hline & Solvent & \multicolumn{3}{c}{ Inhibition zone (mm) } \\
\cline { 3 - 5 } Solvent system & S. aureus & P. aeruginosa & E.coli \\
\cline { 3 - 5 } & Chloroform & 19 & 18 & 17 \\
& Methanol & 22 & 20 & 20 \\
& Water & 0 & 14 & 14 \\
\hline \multirow{2}{*}{ Antibiotic } & Co-trimexazole & 30 & - & 32 \\
& Gentamycin & 20 & 19 & 21 \\
& Ciprofloxacin & 35 & 35 & 38 \\
& Amoxycillin & - & - & 30 \\
& Ceftriaxone & - & 26 & - \\
& Cephalothin & 34 & - & - \\
& Ampicillin & 34 & 30 & - \\
\hline
\end{tabular}


Table 2 Inhibition zones of Aloe sinkatana against Candida albicans, Aspergillus niger, Aspergillus flavus, Tricophyton mentagrophytes, and Phialophorarichardsiae in different solvent systems

\begin{tabular}{llccccc}
\hline & Solvent & \multicolumn{5}{c}{ Inhibition zone (mm) } \\
\cline { 3 - 7 } & & C. albicans & A. niger & A. flavus & T. mentaegraphytes & P. richardsiae \\
\hline \multirow{2}{*}{ Solvent system } & Chloroform & 23 & 18 & 20 & 22 & 20 \\
& Methanol & 22 & 20 & 21 & 18 & 15 \\
& Water & 19 & 0 & 0 & 0 & - \\
\hline Antifungal & Nystatin & 17 & - & - & - & - \\
agents & Ketoconazole $100 \mathrm{mg}$ & - & 27 & 25 & - & - \\
& Ketoconazole $50 \mathrm{mg}$ & - & 24 & 20 & - & - \\
\hline
\end{tabular}

Table 3 Inhibition of growth by Aloe sinkatana against Microsporum cains, and Tricophyton verrucosum in different solvent

\begin{tabular}{llll}
\hline \multirow{2}{*}{ Fungi } & \multicolumn{3}{c}{ Growth inhibition } \\
\cline { 2 - 4 } & Chloroform & $\begin{array}{c}\text { Solvent system } \\
\text { Methanol }\end{array}$ & Water \\
\hline Tricophyton verrucosum & No Growth & No growth & No growth \\
\hline Microsporum canis & Growth & No growth & Growth \\
\hline
\end{tabular}

performed show antimicrobial activity. Two fungi were tested on the antimicrobial activity of $A$. sinkatana, $T$. verrucosum, and $M$. canis were tested in different solvent system of $A$. sinkatana and revealed growth inhibition (Table 3 ). Clearly the effect of $A$. sinkatana extracts against $T$. verrucosum was indisputable since all extracts rendered no growth detectable. M. cains on the other hand showed growth after treatment of one extract which was chloroform. All dermatophytes tested revealed high sensitivity to all extracts. No growth was observed when culturing them on Sabouraoud's dextrose agar.

\section{DISCUSSION}

It can safely be presumed that the major part of a traditional medicine involves the use of plants and their derived active principles, although their use is not always verified by the scientific means, very little and scattered investigations have been carried out searching for plants with antimicrobial activity.

In the present study the phytochemical screening of A. sinkatana showed that the plant contains same ingredients as in $A$. vera such as anthracene, alkaloids, flavonoids, tannins, saponins, carbohydrates, steroids, and reduced sugars. These results are similar to previous results (Arunkumar and Muthuselvam 2009) showing that $A$. vera contains tannin, saponin, and flavonoids and there are findings reported $A$. vera to have mono- and polysaccharides, tannins, sterols, organicacids, enzymes, saponins, vitamins, and minerals (Rodriguez et al. 2010; Nejatzadeh-Barandozi 2013). Thus, this shows that $A$. sinkatana and $A$. vera share almost the same constituents.

Antibacterial activity of $A$. sinkatana against $S$. aureus, P. aeruginosa, and E. coli revealed antibacterial activity in the methanol extract compared to the other extracts. Among the three bacterial organisms tested the maximum growth suppression was observed with $S$. aureus $(22 \mathrm{~mm})$ compared with $E$. coli and $P$. aeruginosa. This finding harmonise to a previous finding, (Arunkumar and Muthuselvam 2009) in which it was shown that $A$. vera leafs inhibited growth of $S$. aureus, S. pyogen, P. aeruginosa, and E. coli. This might be due to the anthraquinones compound which disclosed to have an antimicrobial activity (Ernst 2000). According to available literature there is no work done on antimicrobial activity of $A$. sinkatana and 
accordingly this is the first report on such work.

Antifungal activity of $A$. sinkatana against $C$. albicans, A. flavus, A. niger, Microsporum canis, Trichophyton mentagraphytes, T. verrcosum spp., and Phialophorarichardsiae could be estimated and the revealed maximum antifungal activity with ethyle acetate extract was observed against $A$. niger $(28 \mathrm{~mm})$. This finding is similar to previous findings, where it has been shown that, the maximum antifungal activity of $A$. vera was observed in A. flavus (15 mm) (Arunkumar and Muthuselvam 2009).

Moreover, A. sinkatana extracts have shown to inhibit the growth of fungi that cause tinea since complete inhibition of growth of $M$. canis and $T$. verrucosum was observed.

In the present study, the extracts of $A$. sinkatana leaves revealed antimicrobial properties greater than commercial antifungal agent (nystatin) used for treatment of $C$. albicans and ketoconazole used for treatment of $A$. niger and A. flavus,

In conclusion present study revealed the presence of secondary metabolites in the leaves of A. sinkatana. It was further shown that the plant extracts may be used for the treatment of fungal infections such as ringworm and aspergillosis. The results lend credence to the folkloric use of this plant in treating microbial infection and shows that $A$. sinkatana could be exploited for new potent antimicrobial agents especially antifungal agents. This becomes more relevant as current antimicrobial agents in use are fast loosing effectiveness due to emergence of resistant microorganisms.

\section{REFERENCE}

Almagboul AZ. 1992. Antimicrobial and Phytochemical investigation of Vernonia and other Sudanese medicinal plants. PhD, University of Khartoum.

Arunkumar S, Muthuselvam M. 2009. Analysis of Phytochemical Constituents and Antimicrobial Activities of Aloe vera L. Against Clinical Pathogens. World J Agr Sci. 5(5):572-576.
Bauer KM, Driesen D. 1966. [Cerebral aneurysm and seminoma as a combined malformation. Report on 2 clinical cases]. Med Welt. 46:2492-2494.

Du Plessis L.H, Hamman J H. 2013. In vitro evaluation of the cytotoxic and apoptogenic properties of Aloe whole leaf and gel materials. Drug Chem Toxicol. doi:10.3109/0148 0545.2013.83435.

Ernst E. 2000. Adverse effects of herbal drugs in dermatology. Br J Dermatol. 143(5):923-929. doi:10.1046/j.13652133.2000.03822.x.

Farnsworth NR, Akerele O, Bingel AS, Soejarto DD, Guo Z. 1985. Medicinal plants in therapy. Bull World Health Organ. 63(6):965-981.

Miles RS, Amyes SB. 1996. Laboratory control of antimicrobial therapy. In practical Medical Microbiology, New York, Churchill Livingstone.

Nejatzadeh-Barandozi F. 2013. Antibacterial activities and antioxidant capacity of Aloe vera. Org Med Chem Lett. 3(1):5. doi:10.1186/2191-2858-3-5.

Newall CA, Anderson LA, Phillipson JD. 1996. Herbal medicines: A Guide for Health-Care Professionals. London, England: Pharmaceutical Press.

Agarry OO, Olaleye MT, Bello-Michael CO. 2005. Comparative antimicrobial activities of Aloe vera gel and leaf. Afr J Biotechnol. 4(12):1413-1414.

Pandey R, Mishra A. 2010. Antibacterial activities of Aloe barbadensis to clinically isolated bacterial pathogens. Appl Biochem Biotechnol. 160(5):1356-1361. doi:10.1 007/s12010-009-8577-0.

Reynolds. 1957. Classification of Aloe sinkatana. J African Botany. 23-29.

Rodriguez ER, Martin JD, Romero CD. 2010. Aloe vera as a functional ingredient in foods. Crit Rev Food Sci Nutr. 50(4):305-326. doi:10.1080/10408390802544454.

Sharma D, Lavania AA, Sharma A. 2009. In vitro comparative screening of antibacterial and antifungal activities of some commo plants and weeds axtracts. Asian J Exp Sci. 23:169-172.

Van Gorkom BA, De Vries EG, Karrenbeld A, Kleibeuker J H. 1999. Review article: anthranoid laxatives and their potential carcinogenic effects. Aliment Pharmacol Ther. 13(4):443-452. doi:10.1046/j.1365-2036.1999.0 0468.x. 